\title{
Comment on Andrew Moravcsik, "A New Statecraft? Supranational Entrepreneurs and International Cooperation"
}

\author{
Oran R. Young
}

Andrew Moravcsik's article titled “A New Statecraft? Supranational Entrepreneurs and International Cooperation" is a powerfully argued and provocative contribution to our understanding of the role of individuals in the dynamics of international cooperation. ${ }^{1}$ His revisionist account of the parts played by prominent figures like Jean Monnet and Jacques Delors in the development of the European Union (EU) is sufficient all by itself to ensure that this piece will stimulate vigorous debate.

Yet Moravcsik's reasoning contains a number of significant ambiguities; it leaves several closely related matters untouched. To explore these matters-in a spirit of friendly debate-I consider five issues in this comment: (1) types of leadership, (2) the nature of entrepreneurial leadership, (3) the identity of leaders, (4) the character of institutional bargaining as a setting for the exercise of leadership, and (5) the relationship between the EU and other forms of international cooperation. In the process, I draw on my own prior work-which Moravcsik does not cite explicitly even though he refers to me as a proponent of certain views he seeks to refute. ${ }^{2}$

\section{Types of Leadership}

In seeking to understand roles that individuals play in processes leading to institutionalized cooperation at the international level, many of us have found it helpful to differentiate among several types of leadership. In my own work, I differentiate among three types - structural, entrepreneurial, and intellectual - and seek to identify the circumstances under which each type comes into play. Structural leaders achieve success by devising effective ways to translate power measured in terms of the possession of material resources into influence over the behavior of actors engaged in processes of institution building. The role of Richard Benedick, the chief negotiator

2. Young 1991. 
for the United States, in crafting the terms of the 1987 Montreal Protocol on Substances that Deplete the Ozone Layer is a prominent case in point. Entrepreneurial leaders, by contrast, produce results by helping to broker deals acceptable to parties engaged in competitive-cooperative interactions and, in the process, to dissolve or circumvent the collective-action problems associated with institutional bargaining. Tommy Koh played this role with particular finesse in the negotiations of the 1970s and early 1980s that resulted in the 1982 UN Convention on the Law of the Sea (UNCLOS). For their part, intellectual leaders influence the course of institutional bargaining by producing and disseminating intellectual capital that influences the trajectory of the bargaining process. It is hard to overlook the role that Bert Bolin and his colleagues on the Intergovernmental Panel on Climate Change (IPCC) played in shaping the course of the negotiations leading to the 1992 Framework Convention on Climate Change (FCCC), even though they were not formal participants in the negotiations themselves. The take-home messages here are that entrepreneurial leadership is only one of several types of leadership that are relevant to the development of institutionalized cooperation and that the role of leadership remains an important matter to consider even in cases where there is little or no role for entrepreneurial leaders.

\section{Entrepreneurial Leadership}

But how should we think about entrepreneurial leadership in particular? Why and when are there opportunities for individuals to perform this role in interstate negotiations? Moravcsik answers these questions by developing an informal model that rests on the premise that "informational and ideational asymmetries create windows of opportunity that supranational entrepreneurs exploit to influence interstate negotiations. ${ }^{3} \mathrm{He}$ then proceeds to make the perfectly reasonable point that national representatives are just as sharp and far more numerous than supranational entrepreneurs, so that it is hard to see why the latter are needed to break "bottlenecks in leadership." ${ }^{4}$ But this formulation misses the essential role that entrepreneurial leaders play. As in other processes featuring negotiations among self-interested actors, institutional bargaining in international society is subject to a variety of rigidities arising from the use of threats, promises, committal tactics, and other stratagems on the part of actors seeking to maximize their own payoffs. Protracted and costly efforts to reach closure on the terms of mutually acceptable agreements are commonplace in such settings. Stalemates are by no means uncommon, especially in situations where the rules of the game call for decision making by consensus. It took eight years to negotiate the terms of UNCLOS. Seven years after the signing of the FCCC, the parties are nowhere near consensus on substantive commitments regarding climate

3. Moravcsik 1999, 274.

4. Ibid., 275. 
change. The key actors have been unable to reach agreement even on the terms of a framework convention relating to the management of forests. And these are not exceptional or anomalous cases. In such settings, entrepreneurial leadership, which subsumes a variety of forms of facilitation, conciliation, mediation, and so forth, achieves results by helping parties locked into competitive-cooperative interactions to solve or circumvent a range of bargaining problems. The point is not that entrepreneurs know things that the parties themselves do not know. Rather, they influence the process by "helping the parties to help themselves," a role they are able to play because they are not protagonists in the bargaining process itself.

\section{Identity of Leaders}

What can we say about the identity of the individuals who assume leadership roles in interstate negotiations? Structural leaders are almost always representatives of major actors involved in bargaining processes, an observation worthy of serious attention since there is nothing remotely automatic about success in efforts to translate power in the material sense into effective influence in interstate negotiations. Given the nature of the processes through which they achieve influence, intellectual leaders may have any of a variety of affiliations. Those who shaped public thinking about the problem of ozone depletion were mainly American and British scientists; Bert Bolin is a Swedish scientist who has certainly gained credibility from his association with the IPCC. For their part, entrepreneurial leaders can and do operate from a variety of platforms. As the case of Tommy Koh suggests, entrepreneurs may be representatives of states, so long as they do not come from protagonists or, in other words, states capable of wielding significant structural power in the negotiations at hand. In many issue areas and social settings, "supranational entrepreneurs" are likely to constitute a rare breed, if only because supranational organizations are not highly developed. In this connection, the EU is probably an exceptional case in the sense that it constitutes one of the few instances in international society in which supranational entities, such as the European Commission and the European Court of Justice, are sufficiently well developed to provide platforms for the activities of entrepreneurial leaders. It is possible that other supranational organizations, such as the World Trade Organization, will develop in such a way that they provide platforms for supranational entrepreneurs during the foreseeable future. But the essential point is that there is no reason to conclude from this analysis that entrepreneurial leadership will be uncommon in interstate negotiations or that the efforts of those who assume entrepreneurial roles will seldom succeed. The need for entrepreneurship arises from the occurrence of bargaining impediments that threaten to prevent parties from realizing joint gains or, in any case, to lead to costly delays in the process of arriving at mutually acceptable agreements. Under these circumstances, the protagonists may be quite willing to respond to entrepreneurial initiatives coming from any of a variety 
of sources, so long as doing so offers a way out of the rigidities endemic to the bargaining process.

\section{Institutional Bargaining}

Underlying all these points is a set of-often tacit—assumptions about the nature of the bargaining process associated with efforts to achieve institutionalized cooperation at the international level. Moravcsik has a vision of bargaining at the international level that rests on premises that will be familiar to those who have worked with game-theoretic and economic models of social choice. The players and their individual utility functions are sufficiently well-defined to make it meaningful to specify contract curves or negotiation sets for specific bargaining processes. Because the players are rational, it seems reasonable to expect that they will succeed in reaping joint gains, that the outcomes will be Pareto optimal, and that the players will achieve these results without engaging in protracted and costly negotiations. Under these conditions, it makes sense to suppose that "decentralized bargaining is "naturally" efficient" 5 and that the need for leadership to guide interstate negotiations is not great. But does this vision capture the essential features of what I and others have called "institutional bargaining" in international society? Even in well-defined situations, $N$-person interactions are far more complex and far less deterministic than Moravcsik's vision seems to imply. More important, however, is the fact that institutional bargaining usually occurs in poorly defined situations in which there is considerable scope for integrative bargaining and in which the use of bargaining tactics on the part of players seeking to maximize their individual gains impedes efforts to agree on the terms of constitutional contracts to govern international cooperation. I do not know the EU cases that Moravcsik describes well enough to address the bargaining processes associated with them. But consider the evidence from bargaining processes relating to such matters as arms control, international trade, and the Law of the Sea. SALT I and II involved many years of negotiation, during which the protagonists were spending hundreds of billions of dollars on defense without materially improving their security. The Uruguay Round of trade negotiations took seven years to produce a result acceptable to the major players, and the outcome has been sharply criticized from a variety of perspectives. The 1982 Law of the Sea convention left many important issues unresolved and even then resulted in a set of provisions that took an additional twelve years to enter into force. Under the circumstances, the proposition that interstate negotiations can be expected to produce efficient outcomes with low transaction costs hardly seems credible as a general characterization of institutional bargaining in international society. And the corollary that the role of leadership is of no more than secondary importance in such situations seems suspect as well. 


\section{The EU}

It is possible, of course, that the EU constitutes an unusual setting for interstate negotiations and that Moravcsik's argument about the nature of the bargaining process applies in this setting, even though it cannot be generalized to other settings. To his credit, Moravcsik recognizes this possibility and makes some insightful comments about the generalizability of his analysis. ${ }^{6}$ In some respects, the EU is undoubtedly a special case. The number of parties is comparatively small, the members of the union are relatively homogeneous, the parties have accumulated a great deal of experience in dealing with one another, and the "shadow of the future" is long in this setting. Even under these conditions, however, I would be quite cautious about relying on the assumption that interstate negotiations will yield outcomes that emerge quickly and that are "naturally" efficient. There have been long periods of sluggish progress or even stasis in the development of the EU. Difficulties at the ratification stage have led to major adjustments in the terms of agreements such as the Treaty of Maastricht. Progress on some issues has required the acceptance of provisions designed to allow certain members to go forward while others are permitted to lag behind. There are deep-seated philosophical disagreements about the expansion of the EU to include additional members. None of this is meant to undermine what Moravcsik has to say about the role of supranational entrepreneurs in the five specific episodes of institution building in Europe that he describes. Yet the history of efforts to advance the cause of international cooperation in Europe during the postwar era does not seem to me to justify the cheerful conclusion that we can expect parties to reach agreement swiftly on the terms of arrangements that are Pareto optimal, even under the auspicious circumstances prevailing in this setting.

Where does all this leave us with regard to our understanding of the dynamics of international cooperation? Moravcsik has done us all a service not only by presenting provocative ideas about the role of individual leadership in a forceful manner but also by providing food for thought regarding some larger issues relating to cooperation at the international level. His assessment of the institutional history of the EU is impressive. But when it comes to a broader account of institutional bargaining in international society and, more specifically, the roles that individual leaders play in such processes, it seems to me that his analysis raises more questions than it answers.

\section{References}

Moravcsik, Andrew. 1999. A New Statecraft? Supranational Entrepreneurs and International Cooperation. International Organization 53 (2):267-306.

Young, Oran P. 1991. Political Leadership and Regime Formation: On the Development of Institutions in International Society. International Organization 45 (3):281-308. 